\title{
Varieties of Environmental Labelling, Market Structures, and Sustainable Consumption Across Europe: A Comparative Analysis of Organizational and Market Supply Determinants of Environmental-Labelled Goods
}

\author{
Sebastian Koos
}

\begin{abstract}
The purchase of environmental-labelled goods is an important dimension of sustainable consumption. Existing research on environmental labels and sustainable consumption has a rather individualistic bias. Organizational and structural determinants have only recently sparked attention. In this paper, a comparative framework is used to analyse the impact of organizational varieties of environmental labelling and market supply characteristics on purchases of environmental-labelled goods in 18 European countries. Focusing on labels for organic food and ecological durables, the plurality of existing labels as well as state involvement into labelling are used as the central dimensions constituting the organizational varieties. Market structures refer to the supply of labelled goods and the dominant retailing channels that make up the infrastructure for this dimension of sustainable consumption. After giving an overview on the underlying theoretical mechanisms of the main determinants, country differences in the organization of environmental labelling as well as the market structures are outlined. To analyse the effect of these differences, individual level data of a 2007 Eurobarometer survey on purchases of environmental-labelled goods is combined with organizational and market structural indicators. Using random intercept regression models and controlling for individual socio-economic and aggregate market demand-side factors, like average per capita income, share of post-materialists, and level of generalized trust, only the market supply and retailing structure reveal a robust effect on individual purchases of environmental friendly labelled goods.
\end{abstract}

Keywords Sustainable consumption $\cdot$ Organic food $\cdot$ Eco-label $\cdot$ Labelling $\cdot$ Europe

\section{Introduction}

Today, a great variety of environmental label schemes aimed at guiding and promoting sustainable consumption exists throughout Europe. These product labels form part of a new

S. Koos $(\bowtie)$

Faculty of Social Sciences, University of Mannheim, A5, 68131 Mannheim, Germany

e-mail: skoos@sowi.uni-mannheim.de 
environmental policy, which is market-based, consumer driven, and jointly formulated and implemented by the state and private associations (Mol et al. 2000). The main aim of environmental labelling is to promote and support sustainable consumption, which has been defined with reference to the Brundtland report as "minimising the use of natural resources, toxic materials, and emissions of waste and pollutants over the life cycle, so as not to jeopardise the needs of future generations" (OECD 2002, p. 16). While this definition implies a change in both the levels and patterns of consumption (Fuchs and Lorek 2005), environmental labels promote sustainability only in the second way, by providing information to the consumer that products meet or fail to meet certain environmental standards. In focusing on environmental friendly labelled goods, a rather restricted meaning of sustainable consumption is used here, thus neglecting the important issue of consuming less. However, especially in affluent societies, empowering the consumer to buy sustainable products by providing environmental labels is one important step towards increasing sustainability (Boström and Klintman 2008; Jordan et al. 2004; Krarup and Russell 2005; OECD 2005).

In the last decades, much has been done politically to facilitate the use of labelling schemes by introducing common legal frameworks, for instance, by the European Commission and a multitude of public, but also private, transnational, national, as well as regional environmental labels (Murphy 2001; Schmid 2007). Environmental label is used as an umbrella term here, referring to organic food labels and eco-labels for non food durables, including energy efficiency labelling for household appliances. The organization of these labels, as well as the supply of and demand for labelled products, differs strongly between European countries (Dabbert et al. 2004; Jordan et al. 2004; Padel et al. 2009). While existing research mostly concentrates on (demand-side) individualistic explanations of sustainable consumerism (Bjørner et al. 2004; Micheletti et al. 2004; OECD 1997, 2005; Stolle et al. 2005; Teisl et al. 2008; Thøgersen 2000; van Amstel et al. 2008), only recently there has been an increasing focus on institutional, structural, and cultural determinants (Jordan et al. 2004; Michelsen et al. 1999; Padel and Midmore 2005; Sønderskov 2009; Spaargaren 2004; Terragni and Kjærnes 2005; Thøgersen 2005, 2010). Yet, only scant empirical work has systematically tested the influence of political/organizational and supply-side market characteristics of environmental labels on the purchase of environmental-labelled goods. Hence, the following questions are addressed here: How do countries differ in the way they organize environmental labelling and provide environmental-labelled goods on the market? Furthermore, do these country differences in environmental labelling and market structures affect consumer behaviour?

The organizational diversity of environmental labelling schemes is analysed along two main dimensions: The level of state involvement in environmental labelling and the plurality of environmental labels existing within a country. It can be argued that when states assume an active role in environmental labelling, then trust in and recognition of the respective labels increases (Sønderskov and Daugbjerg 2010; Teisl and Roe 2005). The multitude or fragmentation of the environmental labels, in turn, is expected to increase confusion about standards, thereby decreasing the propensity to buy environmental-labelled products (Aschemann et al. 2007; Hamm and Gronefeld 2004).

Market structures refer to the supply of environmental-labelled goods and the dominant type of retailing outlets. Here the assumption is that the greater supply typically associated with larger retail stores potentially increases the likelihood of purchasing environmentallabelled goods. Using a comparative approach, the importance of organizational and market differences is assessed by empirically testing them against well-established demand-side explanations, like national differences in average income, value orientations, and 
generalized trust. For this purpose, individual level data from the 2007 Eurobarometer survey on self-reported purchases of environmentally friendly labelled products in 18 European countries is combined with a set of macro-structural indicators. To account for the hierarchical data structure, individuals nested within countries, the aggregate level of the explanatory concepts, as well as the multiplicity of control variables on individual and aggregate level, a multilevel research design is adopted.

In the next section, a conceptual model is outlined which allows one to distinguish analytically between supply- and demand-side explanations in the market as well as in the political/organizational dimension of environmental labelling (Thøgersen 2010). Focusing consecutively on information, trust, and opportunity structures, a theoretical argument is developed that explains how the organization of environmental labelling as well as the retailing structures and market supply affect purchasing behaviour. After giving an overview of the varieties of environmental labelling and market structures in Europe, relevant control variables are discussed. The "Empirical Analysis" section presents the data, method, as well as the descriptive and multivariate results. In the conclusion, the limitations of the findings and policy implications are discussed.

\section{A Conceptual Model}

To organize and evaluate the multiple determinants that have been established as potential explanations for the purchase of environmental-labelled goods, a conceptual model developed by Thøgersen (2010) is outlined. Although this framework initially emerged from a review on determinants of country differences in organic food consumption, it can well be extended to the consumption of all kind of environmental-labelled goods. The model first distinguishes between a market and a political dimension. This reflects the main actors (public and private) involved in environmental labelling. Secondly, within these dimensions, the model further differentiates between supply- and demand-side factors (see Fig. 1).

In the political realm, the distinction between supply and demand denotes the activities of the state that either support the production (supply) or try to facilitate the sales of environmental-labelled goods (demand). The former is mainly achieved by introducing

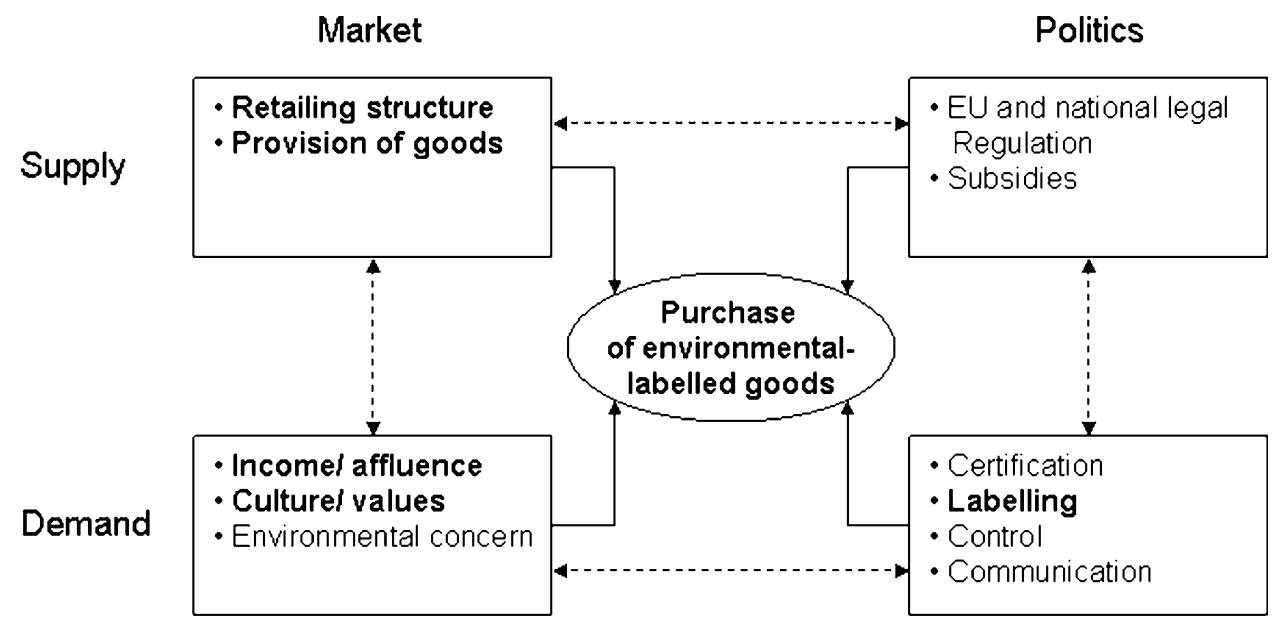

Note: Bold determinants are included in the analysis

Source:Thøgersen 2010 , p. 6 , slightly changed depiction.

Fig. 1 Conceptual model of determinants influencing the purchase of environmental-labelled goods 
legal regulations and subsidies, for instance for organic farming. In Europe today, the European Commission sets binding standards for organic and ecological goods from which individual member states cannot deviate (Jordan et al. 2004; Schmid 2007). Subsidies, however, are still subject to individual member states within certain limits (Dimitri and Oberholzer 2005). The demand-side strengthening activities are mainly connected to labelling, certification, the control of both, and the provision of information (Dabbert et al. 2004; Thøgersen 2010). Here, the state has an important opportunity to influence the recognition of and trust in labels. Denmark is an often-mentioned example of successful state engagement in the labelling and certifying of organic food, leading to high consumer trust in the label as well as high consumer recognition (Hofer 2000; Sønderskov and Daugbjerg 2010).

On the one hand, the market dimension refers to the resources and motivations of consumers (demand) and on the other hand to the production and retail characteristics that outline the opportunity structures for the purchase of environmental-marked goods (supply). Consumers' resources or "abilities" are determined by their monetary means, such as income, but also by education, which enables consumers to understand the complexities behind production and consumption. The motivations of consumers can be guided by certain values and existing norms, but also by environmental concern (Thøgersen 2010). Supply-side factors include the availability of products, for instance the supply of organic food through local farmers. Moreover, distribution channels, through which products are supplied, i.e., local markets versus large hyper-markets, influence the availability for large groups of consumers (Wier and Carlverley 2002).

The outlined factors are not exhaustive, but reflect the most common determinants of the purchase of organic and eco-marked products. Furthermore, mutual influences between market and political domain as well as supply and demand exist. Thus, increasing demand for organic food in the long run will result in a heightened supply of organic products. Likewise, subsidies for organic farming will increase market supply (Dimitri and Oberholzer 2005). Nevertheless, the conceptual model allows for a disaggregation of the complexities and an analytical differentiation of single causes of this dimension of sustainable consumption. Because legal conditions are quite similar in all countries and there is a lack of comparable data on subsidies, the main focus in the following is on the political/organizational demand- and market supply-side factors. Demand-side explanations are mainly discussed as control variables.

\section{Varieties of Environmental Labelling and Market Supply Structures}

\section{Theoretical Background and Literature Review}

Environmental labels are market-based voluntary policy instruments often jointly organized by the state and private associations, like environmental organizations and farmers' associations, that identify "overall environmental preference of a product within a specific product category based on life cycle considerations" (Global Ecolabelling Network 2006, p. 1). According to the International Standards Organization (ISO), there are three types of environmental labels that differ in the type of information presented to the consumer and the extent of external certification. Here, the focus is on the most common type I schemes, whose certification is based on a voluntary, multiple-criteria third party evaluation (OECD 1997). ${ }^{1}$

\footnotetext{
${ }^{1}$ Private corporate environmental labels unfortunately cannot be considered in this analysis due to the problem of collecting adequate data on them.
} 
The Political and Organizational Dimension of Environmental Labelling: Trust and Information

Product labels are informational devices that signal a specific quality of a product, which in most cases cannot be directly observed by the consumer. In doing so, environmental labels reduce the complexities surrounding the production and distribution of goods and transpose them into a dichotomous claim of meeting a standard or not. The underlying rationale in labelling is the governance of consumer behaviour through information provision (Boström and Klintman 2008; Thøgersen 2002). In successfully organizing labels for consumers, the main tasks are to agree on certain standards, provide product labels that convey the standard in an understandable, trustful way, and disseminate information on these labels (Boström and Klintman 2008; Dabbert et al. 2004; Krarup and Russell 2005). Hence, information as well as trust in the source of information appear pivotal in connection to the organized communication of standards (Boström and Klintman 2008; Teisl and Roe 2005; Youssef and Abderrazak 2009).

Consumers are generally handicapped by an information asymmetry, referring to their deficient knowledge on the quality and pricing of goods in comparison to producers (Nelson 1978). Eco-labels are means of overcoming this asymmetry by providing environmental classifications (Russell et al. 2005). These classifications and resulting standards need to be recognized and understood by the consumer to be relevant in the course of behaviour (Thøgersen 2000). Thus, consumers need to be educated about the content of standards and the labels that signal these standards. Furthermore, these labels and the issuers need to be trusted. According to Boström and Klintmann (2008, p. 174) "[d]ealing with trust and (mis)trust is at the heart of green labelling activities." Confidence in the information conveyed through environmental labels is crucial for the willingness to consider labels in a purchasing decision (Thøgersen 2002). Therefore, labels and the organizations that own and manage such labels are responsible for generating some form of "simple trust" in their activities (Boström and Klintman 2008, pp. 41-42). Once established, trust is an important mechanism that decreases transaction costs, otherwise necessary to search for and control information (Chiles and McMackin 1996; Teisl and Roe 2005).

Two characteristics in the organization of labelling have been emphasized as promoting the trust in and comprehension as well as awareness of labels: The plurality of existing labels and the level of public or state involvement in labelling (Aschemann et al. 2007; Crespi and Marette 2005; Teisl and Roe 2005; Thøgersen 2002). The number of labels in a country can, on the one hand, be a sign of a differentiated and developed market for sustainable goods; on the other hand the plurality or fragmentation of labels can lead to consumer confusion (Aschemann et al. 2007; Hamm and Gronefeld 2004). If many different labels exist that make similar, but slightly different claims, it is increasingly difficult to evaluate the information of labels. Thus, a plurality of environmental labels is likely to undermine the idea of a clear-cut signal. In an economic approach, Youssef and Abderrazak (2009) show that under the assumption of complete information, a multiplicity of environmental labels increases the likelihood of buying environmental labels, due to highly differentiated alternatives. However, in (more realistic) situations, characterized by incomplete information, a pluralism of labels has the reverse effect (Youssef and Abderrazak 2009). In line with transaction cost economics (Williamson 1981), a multiplicity of environmental labels increases search cost and therefore decreases the likelihood of purchasing environmentally friendly goods, especially for people that are only moderately committed to the environment. 
Environmental labels are often jointly organized by the state and private actors. But especially the role of the state is crucial in regard to the outlined role of information and trust. First of all, states have the potential to limit the number of labels in a country by having a mandatory public label or prohibiting the use of other labels. Secondly, in contrast to most Non Governmental Organizations (NGOs), states posses the resources to communicate and promote a label and thereby increase consumer awareness and recognition. Thirdly, states in Europe are democratically legitimized and hence accountable to all citizens, whereas associations like NGOs are only accountable to their members (Boström 2006). Therefore, public involvement into labelling and certification increases legitimacy and acceptance of environmental labels (Crespi and Marette 2005). Finally, since labelled products often command a prize premium, green washing by producers is a serious issue for environmental labels. Controlling and penalizing producers for misuse of labels can best be executed by resourceful public actors. There is some empirical support that state involvement promotes consumer confidence in environmental labels (Roosen et al. 2003; Sønderskov and Daugbjerg 2010; Zanoli 2004). However, even if there is strong state involvement there still might be a high fragmentation or plurality of labels. In Germany, for instance, there have been at least nine organic food labels, but only since 2001 has the state introduced its own label, which was strongly supported (Richter 2005). The discussion of information, trust and the role of the state, and the number of labels can be summarized in the following two hypotheses: H1: Strong state involvement in environmental labelling increases the likelihood of consuming environmental-labelled goods. H2: A high number of environmental labels within a country decrease the likelihood of buying environmentallabelled goods.

\section{The Market Dimension of Environmental Label Supply: Opportunity Structures}

Supply-side market factors are likely to play a pivotal role in promoting and establishing the consumption of environmental-marked goods. The underlying theoretical argument is rather straightforward. Products need to be available to be purchased. Thus the availability and price of goods directly determine the opportunity structure to acquire them. According to Robert Merton (1996, p. 153), "(o)pportunity structure designates the scale and distribution of conditions that provide various probabilities for individuals and groups to achieve specific outcomes." The scale and distribution of conditions surely extends beyond supply-side factors, i.e., to available income. However, the amount and number of goods carrying an environmental label, as well as the distribution through certain retailing channels, provide consumers with a varying infrastructure for sustainable consumption (Southerton et al. 2004). More specifically, the provision of labelled goods depends on the share of labelled goods, produced or imported within a country. In addition, these products have to be available at retailing outlets.

The cultivation of organic food (Willer and Kilcher 2009) and also the manufacturing of eco-labelled goods differ immensely between European countries (Jordan et al. 2004; Kern et al. 2001). Similarly, there is a huge variation in the distribution channels of environmental-labelled goods. Even though all over Europe there is an ongoing concentration process in retailing structures, especially in the food market (Vorley 2007), differences in the retailing structures persist (Clarke et al. 2002). In many Northern European countries, large retailing stores dominate, whereas in southern and eastern European countries smaller stores and producer markets are more widespread (Clarke et al. 
2002, p. 49). ${ }^{2}$ Larger stores usually offer a greater selection of goods, whereas smaller stores are more or less confined by space to a limited assortment (Grunert et al. 1996). Following this reasoning, it is easier to promote the consumption of environmental-labelled goods through larger retailing outlets that are able to provide a broad selection of items and which are frequented by many consumers. If a large share of environmental-labelled goods is only supplied through specialized stores, then consumers must make extra effort to get there to buy labelled goods. In such a setting, it might be more difficult to mainstream the buying of environmentally marked goods. Furthermore, it has been shown that large retailing chains are important actors in establishing markets for eco-products, for instance the Austrian Billa supermarkets (Hofer 2000), but also large retailing chains like Carrefour in the Czech Republic (Dytrtová 2008). Two main hypotheses can be developed from this discussion: H3: A large supply of environmental-labelled goods within a market increases the likelihood of purchasing these goods. H4: A large relative share of small retailers in a country, reflecting decentralized retailing structures, decreases the likelihood of buying labelled products.

\section{Varieties of Environmental Labelling and Market Structures across Europe}

Since the late 1970s, when the first eco-label named "Blue Angel" was introduced in Germany, numerous environmental labels have been established throughout the world, both for food and durables (Harrington and Damnics 2004; Kern et al. 2001; Willer and Yussefi 2007). As both durables and food are important everyday commodities, they will be considered together. Both eco and organic products contribute to some collective good, environmental sustainability. However, as Hamm and Gronefeld (2004) point out, organic food produces an additional private benefit for being perceived as healthier than normal food. Hence, health considerations and thus self-interest may play a bigger role in the decision to buy organic than in purchasing eco-labelled goods that do not equally contribute to personal welfare (Sønderskov 2009). However, most eco-labels include energy efficiency criteria for household appliances (Harrington and Damnics 2004) and, hence, contribute to self-interest by increasing cost-efficiency. Even though this reasoning does not extend to all products covered by eco-labels, like detergents or toilet paper, there is a sufficient overlap in the mix of private and environmental public benefits to consider both organic and ecolabelled goods together. ${ }^{3}$

To asses and operationalize the above introduced constructs of interest, a broad variety of data has been compiled. Table 1 gives an overview of the varieties of environmental labelling and the market structures and provides the data sources for each construct. In the following, each indicator will be discussed in turn.

State involvement in environmental labelling has been operationalized by the presence of a state label for eco and organic products. All national eco-labels in Europe are founded and hosted either by state agencies as in the case of Germany (The Umweltbundesamt), national standards organizations (France), or as in the case of The Netherlands, a foundation (Stichting Milieukeur; Jordan et al. 2004). In most cases, state involvement can be

\footnotetext{
$\overline{2}$ More recent data (see the indicator "density of small retailers" in Table 1) confirm the persistence of these patterns.

${ }^{3}$ Nevertheless, the mixture of organic and eco-labelled products in the present analysis might run the risk of providing biased results. While some people might perceive only eco-labels as signaling environmental sustainability, others might well see organic products as sharing this quality. Future analysis should seek to disentangle organic and eco-labelling and the purchase of the respective goods to provide an insight into the differing motivations and understandings of environmental labelling.
} 


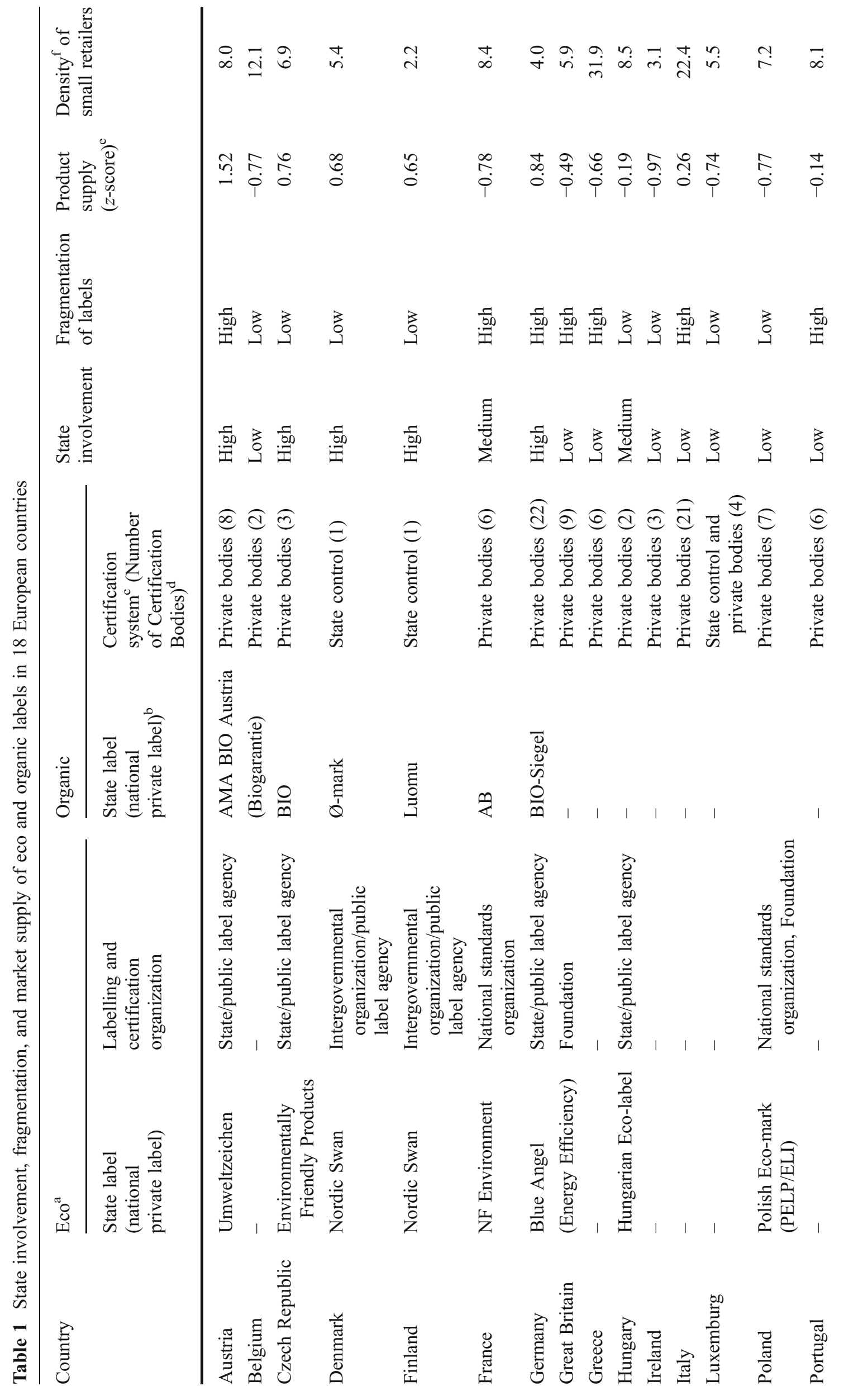




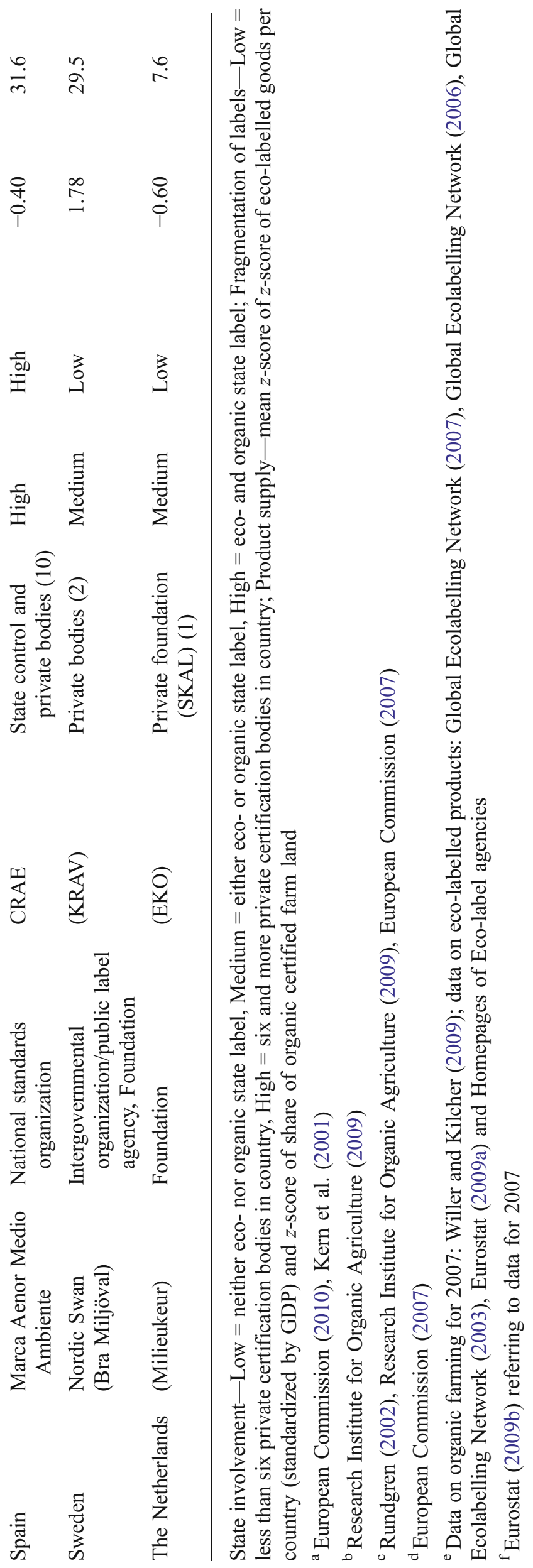


described as quite high. The Nordic Swan, a transnational label for the Scandinavian region, is founded and governed by the Nordic Council of Ministers and thus state involvement can also be described as high (Kern et al. 2001). Two countries, Great Britain and Poland, have an "energy efficiency label," which in both cases is organized by a private trust (Harrington and Damnics 2004). Six of the 18 countries analysed have neither a national public nor private label and are thus classified as having low state involvement in regard to ecolabelling. Producers in those countries can obtain the European Eco-label ${ }^{4}$ or apply for one of the national labels of the other European countries. Certification is organized in a slightly different way in each country, but is mostly passed on to an independent public or private laboratory.

State involvement in organic labelling is more nuanced, since the label and the certification are either completely public, private, or a mix of both. Altogether, the group of countries relying on the state in the organization of organic labelling is similar to the group that has a state eco-label. There is no country which has state involvement in organic labelling, but not in eco-labelling. (The only exception being Luxembourg, which has some very limited direct state certification (Rundgren 2002), yet it does not have a state label). However, there is a group of countries that while having a state eco-label, decided for a private organization of the organic label (Sweden, The Netherlands, Poland, and Hungary). Sweden and The Netherlands each rely on a single privately organized organic label (Boström and Klintman 2006; Hofer 2000). In Poland and Hungary, in addition to the labels of farmers' associations, labels of private for-profit certifiers are available (Kovács 2008; Metera 2008). Denmark, Finland, and Spain have the most rigorous state involvement in organic labelling, where not only the organic label, but also the certification process is carried out directly by the state (Dimitri and Oberholzer 2005). In all other countries, private certification bodies, which have to be authorized by the state, handle the certification process (European Commission 2007; Rundgren 2002). Combining state involvement in eco- and organic labelling, three groups can be distinguished that either have a state label for both eco and organic goods (high state involvement), for one of these (medium state involvement) or, thirdly, totally rely on private label initiatives (low state involvement).

To assess the fragmentation or multitude of labels existing within a country is a difficult task since there is no data for the exact number of organic or environmental labels. Therefore, the fragmentation indicator is solely based on a proxy for organic labels, as the number of authorized certification bodies within a country is published by the European Commission (2007). This seems a reliable and valid indicator for most certification bodies that issue their own label beside the labels of farmers' associations or state labels as in Austria. Comparing the number of certifiers to the number of labels (for the countries where some information is available), there is a strong relationship between both figures. Germany, for instance, the country with the highest number of labels by farmers' or producers' associations (nine; Richter 2005), has also the most certification bodies (22). Sweden, on the other hand, has two certifiers of which one organizationally belongs to the national private KRAV label. One problem with this kind of operationalization might be that countries such as Italy, with its high number of certifiers, also have a high share of organic exports. Nevertheless, Italy has a high number of farming associations and labels too (Pinton et al. 2008). The fragmentation index has been dichotomised. Countries having

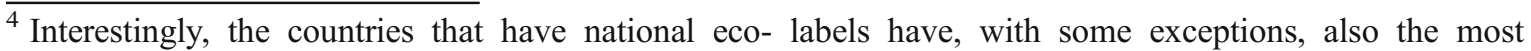
products with the EU eco-seal.
} 
less than the overall country mean of six private certifiers are coded as low fragmented. Six or more certifiers are used as an indicator of a highly fragmented labelling landscape.

For assessing the market retail structure, the number of small retail shops (defined as shops employing less than ten people) has been standardized by population size (per 100,000 citizens). Countries with a large number of small retail outlets have a fragmented retailing structure dominated by small stores. To control for the validity of the density of small retailers, the correlation between this indicator and the share of organic products marketed through the retail trade is estimated (Schaer 2009). The two figures are moderately correlated (Pearson $r=.61, p<.05$ ).

Lastly, the supply of labelled products has been operationalized with an index that comprises data on non food eco-products and the share of agricultural farm land that is organically farmed. Data for environmental-labelled products have been gathered from different sources (see sources below Table 1), standardized by the size of the economy (gross domestic product per capita, GDP) and transformed into a $z$-score. The numbers of products that carry the EU Environmental label have also been considered for each country. For organic farming, the share of organic agricultural farmland was used, as well by transforming it into a $z$-score. By taking the mean of both scores (Pearson $r=.44, p<.1$ ), an index of market supply with environmental-labelled products has been constructed. Obviously, this approach does not take into account imports and exports of products. As reflected by the modest correlation of the two scores, imports and exports might have a significant impact on the availability of sustainably labelled products. Nevertheless, this is the best possible operationalization of market supply. The higher the $z$-score the more environmental-labelled products are available on the domestic market.

\section{Market Demand-Side Explanations of Sustainable Consumption}

The market demand-side factors of the consumption of environmental-labelled products, presented in this section, serve only as control variables. Thus, they are introduced into the statistical analysis to evaluate the robustness of the effects of the supply-side market and organizational characteristics. Therefore, the explanatory factors will be outlined only very briefly. As shown in the conceptual model, two dimensions of consumer demand can be discerned: Abilities and motivations.

Ability-based approaches explain the purchase of environmental-labelled products by the opportunities provided through material resources, like income or assets. From an economic perspective, sustainability is assumed to be a costly good. Hence, the willingness to invest in the environment competes with other needs such as further material acquisition or entertainment. In this perspective, sustainability becomes a "luxury good" (Baumol et al. 1979), the demand for which depends on the presence of sufficient material resources. Thus with increasing income the demand for labelled goods is expected to rise. Findings on the effect of income both on macro and micro level yield mixed empirical support, however (Micheletti and Stolle 2005; Sønderskov 2009; Strømsnes 2005). Moreover, there is a clearcut relationship to organizational and supply factors. If actors do not possess the relevant means to buy labelled products, then trusted and well-communicated labels, as well as easy access to labelled products, do not make a difference.

Furthermore, motivational factors are crucial for demanding sustainable products. Especially pro-environmental and post-materialist value orientations are highly important for acting sustainably (Diekmann and Preisendörfer 2003; Inglehart 1995). The value change from materialist to post-materialist values in the last four decades is likely to have 
affected the development of sustainable consumption in a profound way (Inglehart 1997). The rationale behind motivational factors is that only if individuals value the environment and prefer sustainable to unsustainable products, will they commit resources to sustainable activities. If citizens do not have a preference for environmental protection, even if environmental-labelled products are easily available and labels are trusted, consumption of environmental-marked goods will not prosper. Empirically, pro-environmental values and attitudes have uniformly been shown to affect organic food consumption positively (Guido et al. 2009; Sønderskov 2009) and green consumerism more generally (Sparks and Shepherd 1992).

A third factor, which has been related to sustainable consumption and other forms of environmental protection, is generalized trust (Sønderskov 2009). Trust is a relational concept that depends on the evaluation of social qualities of fellow citizens. Especially in the provision of collective goods, the trust in other people not to free ride is important for an individual's decision to pay a premium to support the commons (Ostrom 1990). The level of trust is important not only on the individual level, as a personal characteristic, but also on group or aggregate level, reflecting the general social culture of a society and its potential for effective governance. Empirical findings suggest that the role of trust might be stronger for pure public goods, such as goods produced by recycling, and less so for joint goods, such as environmental-labelled products that produce some additional private benefit (Sønderskov 2009). Nevertheless, as outlined above, trust plays an important role in regard to labelling. Generalized trust might extend to the organizations that are in charge of the labelling. Thus in high-trust societies, it might be less important who governs the labelling because actors' level of generalized trust comprises not only fellow individuals, but also public and private organizations.

Many other variables might potentially mediate the impact of institutional and structural antecedents of the purchase of environmental-labelled goods. While the above-outlined factors play a central role in the existing literature on sustainable consumption, other factors might also confound the effect of organizational and market supply-side arrangements: The quality of the natural environment might exert a direct signal that some action has to be taken, and thus, contribute to the set of motivational variables (Dunlap et al. 1993). Proenvironmental shopping behaviour might be affected by individual or collectively shared environmental concern (Inglehart 1995). Environmental movement organizations can create frames of environmental issues that are important for understanding the public consequences of private actions (Holzer 2006). Specific consumer cultures and traditions might constrain the consideration of alternative ways of consuming as in the case of groups that centre on conspicuous consumption practices (Veblen 1949). Furthermore, specific socio-economic characteristics seem to play an important role (Boström and Klintman 2008). Women tend to buy sustainable products more often than men (Goul Andersen and Tobiasen 2004; Micheletti 2004; Strømsnes 2005), which may, however, just be because they still do most of the shopping. Very young and old people buy fewer sustainable products than do people aged 26 to 55 (Strømsnes 2005) and people with higher education generally tend to be more environmentally friendlier than people with lower formal education (Ferrer and Fraile 2006; Goul Andersen and Tobiasen 2004). Due to data restrictions, not all variables that have a possible effect on the purchase of environmentallabelled goods and that potentially mediate the effect of the central independent variables can be controlled.

One important factor in this regard, although not part of the market demand-side characteristics discussed in this section, is the supply-side intervention of states through subsidies for environmental-labelled goods. This dimension cannot be controlled here due 
to a lack of data, but there is ample evidence that government support has been a driving factor in conversion to organic farming (Dimitri and Oberholzer 2005), which in turn directly affects the market provision of labelled goods.

\section{Empirical Analysis}

Data, Variables, and Method

For the empirical analysis, data from the 2007 Special Eurobarometer "[a]ttitudes of European citizens towards the environment" (68.2), provided by the Gesis Research Data Center (www.gesis.org), were used (European Commission 2008). The Eurobarometer is a representative multinational survey of European citizens on standard and special topics by request of the European Commission. Containing information for 26,730 respondents in the 27 member states of the European Union on the purchase of environmental-labelled products and some additional variables on environmental attitudes, the dataset is well suited for the analysis. After cleaning the data and limited by the availability of macro data regarding labelling characteristics, 17,416 individuals living in 18 countries remained for the analysis.

The dependent variable "purchases of environmental-labelled goods" is a dummy $(0,1)$ based on the following question: "Have you done any of the following during the past month for environmental reasons?" Out of a list with eight possible answer categories (multiple answers were allowed), respondents could choose the following statement: "Bought environmentally friendly products marked with an environmental label." The dependent variable was coded one if the respondent chose this answer and zero if this answer was not selected.

To validate that the single item used for the analysis is really measuring the purchase of environmental-marked goods, correlations between the aggregate responses in the Eurobarometer survey and data on organic food consumption in Europe for 2007 (Padel et al. 2009, p. 162) have been estimated. Although such data has to be handled with care for being compiled from very different sources, a strong correlation (Pearson $r=.81, p<.001$ ) between the Eurobarometer 2007 country means of buying environmental-labelled goods and the share of organic food of the total market (within 15 overlapping countries) can be observed. The per capita expenditure for organic consumption in all 18 European countries of the Eurobarometer survey shows an equally high correlation with Pearson $r=.79$ ( $p<.001$; see Fig. 2). Even though no data for eco-non food labels is available, the strong correlation showing that the country ordering of organic food consumption is similar to the order of countries produced by the dependent variable used here lends some support to the validity of the dependent variable. Thus, the Eurobarometer variable seems to be a reliable and valid measure of the purchase of environmental-labelled goods.

The main independent variables are operationalized as follows: State involvement is measured by three dummy variables $(0,1)$, for low (reference category), medium, and strong state involvement. Plurality of labelling arrangements was likewise coded as a dummy. If there are multiple labels in a country, it is coded one and zero for a low number of environmental labels. Retailing structures is a continuous variable (see Table 1). A high value indicates a high share of small retailers in a country. Market supply with labelled goods is also a continuous variable (see Table 1), where a high $z$-score indicates the availability of a high number of environmental products. 
Fig. 2 Mean of respondents that bought environmental-labelled products (in \%) and per capita expenditure on organic food (in $€$ )

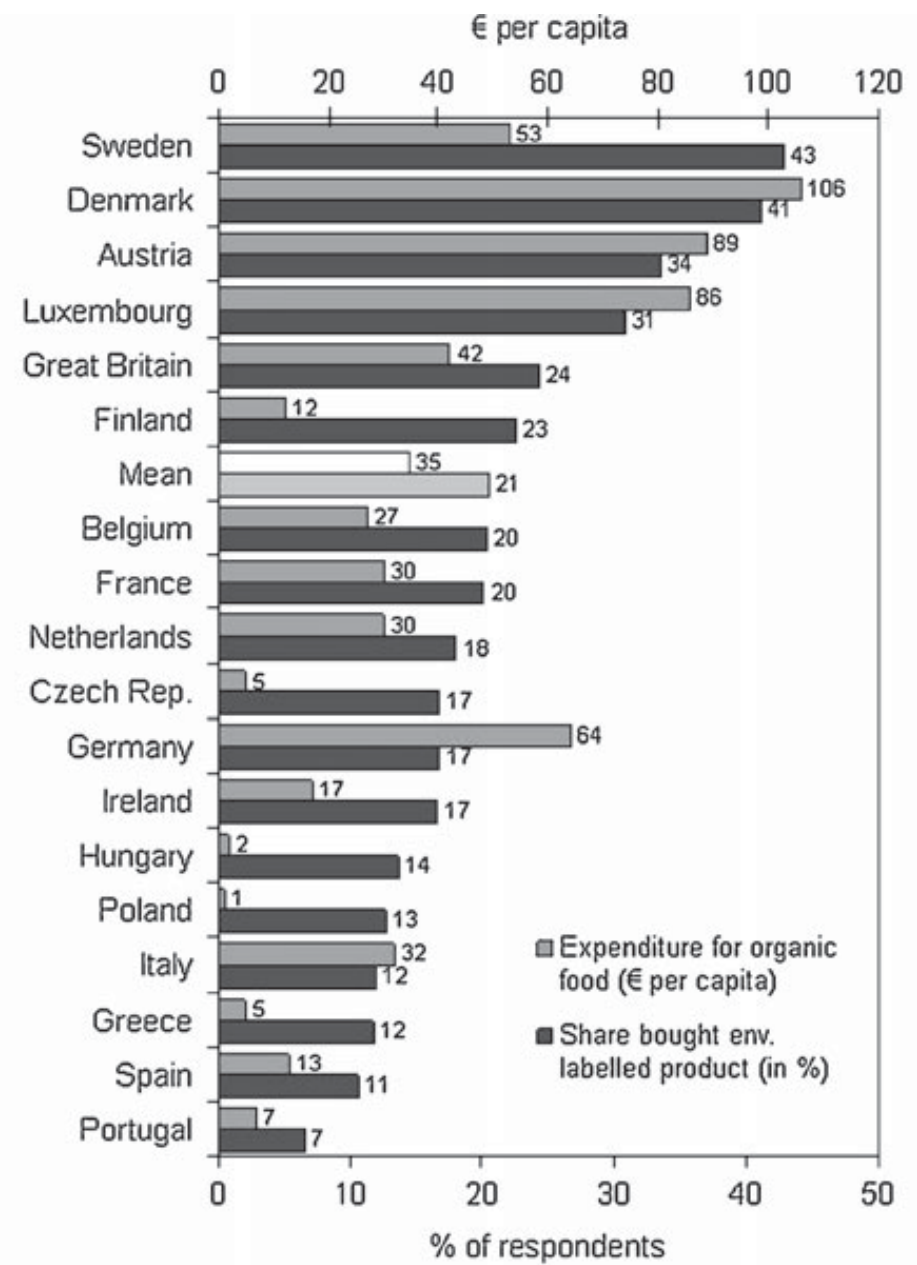

Source: Eurobarometer 68.2; own calculations; data on organic food taken from Padel et al. 2009 , p. 162.

All control variables have been lagged by 1 year, thus they relate to the year 2006, if not indicated differently. The average per capita income is the GDP in Power Purchasing Parities in 2001 US\$ (in thousands) taken from the World Bank (2009). Post-materialist value orientations have been gathered from the European Value Study (EVS 2006) as the aggregated share of people that are ranked as post-materialists on the Inglehart Value Scale given in the EVS data. The EVS data were collected in 2005, resulting in a 2-year lag. Trust is constructed on the basis of three questions in the European Social Survey (ESS) of 2006 with answer scales ranging from zero to ten: "generally speaking, would you say that most people can be trusted (10), or that you can't be too careful in dealing with people (0)?"; "do you think that most people would try to take advantage of you (0) if they got the chance," or would they try to be fair (10)?; "Would you say that most of the time people try to be helpful (10) or that they are mostly looking out for themselves (0)?" The average of the mean score of all three items is used as a measure of generalized social trust. ${ }^{5}$

Pro-environmental values on the micro level were operationalized by building an additive index of two questions on the personal value of environmental protection: "How important is protecting the environment to you personally? (four answer categories from very to not at all important)" and agreement with the following statement: "Environmental protection must been given priority over the competitiveness of the economy." The former

\footnotetext{
${ }^{5}$ Country scores for Greece, Luxemburg, Italy, and the Czech Republic had to be estimated based on the 2004 round of the ESS since those countries did not participate in the 2006 survey.
} 
variable was recoded into a dichotomous construct. Thus, after combining the two variables, pro-environmental attitudes are measured on a three-point scale. Gender is a dummy variable, which is coded one for females. Age is measured in years and in addition to the normal age variable, a squared term of age is included in the analysis to model the expected inverted U-shaped effect of age. Education is measured by three variables that denote primary, secondary, and tertiary education. The education variable is based on a Eurobarometer question that asks for the age at which the respondent finished full-time education (unfortunately the only measure of education available in the Eurobarometer surveys). When respondents gave an age of 15 to 19 years they were coded as having secondary education. An age below 15 years, when schooling ended, indicates primary education or less; an age of more than 19 years is coded as tertiary education (cf. Pfeiffer 2009). For the absence of an income variable, social class was included as a proxy. The class scheme is built on occupational categories, which are quite likely linked to income. However, class includes more than just economic information on the respondents. As Bourdieu (1984) nicely shows, class position is also connected to a certain habitus and taste. The class variable is built on the Erickson-Goldthorpe five class scheme (Erikson and Goldthorpe 1992), coded along the pre-structured occupational categories and introduced as a set of dummy variables.

To analyse the data, logistical random intercept regression models were estimated using Stata 10 (Rabe-Hesketh and Skorndal 2008). Multilevel models of this sort are frequently used in cross-cultural research to account for the hierarchical data structure of individuals nested within countries (Van de Vjver et al. 2008). These models provide for the fact that two randomly chosen individuals from the same country will be more similar than two individuals from different countries. "[S]tandard statistical tests lean heavily on the assumption of independence of observations" (Hox 2002, p. 5), an assumption which is clearly violated when using cross-country data of individuals and which would lead to "spuriously significant results" (ibd.). Random intercept models allow an unbiased estimation of standard errors in clustered data and therefore are well suited for this kind of research. Furthermore, when applying a multilevel research design, the large number of respondents allows for control of socio-demographic factors on the micro level, to give more degrees of freedom to test macro level determinants. This also decreases the likelihood of multicollinearity because fewer macro variables need to be taken into account. Another rather theoretical argument for why a multilevel design should be given priority over a regression on country level is the opportunity to model constructs on the level where they exert their influence. Labelling arrangements are supra individual and therefore, part of a higher aggregation level, whereas sustainable consumption is an individual level decision. To check for multicollinearity on the macro level variables, a correlation analysis was conducted. The variables used were all correlated below Pearson's $r=.6$. Thus multicollinearity does not seem to be an issue in the analysis.

To assess the model fit, the deviance $(-2 * \log$ likelihood) is estimated for each model (Snijders and Bosker 1999). Subsequently, the delta $(\Delta)$ of the deviance between a benchmark model (here, the benchmark is the model containing the individual level variables) and a model containing macro level variables is estimated. All models estimated are tested against the benchmark model. A high delta deviance signals the improvement of the model fit. To assess whether the change in the deviance reflects a significant improvement in the overall model fit, a likelihood ratio test is performed and reported by a significance star behind the delta deviance (Snijders and Bosker 1999). Furthermore, the residual intra class correlation (ICC) is estimated, which indicates how much of the variance in buying environmental-labelled goods can be accounted for on the macro level, 
considering the variables in the model (Snijders and Bosker 1999). The ICC is estimated as the macro level variance divided by the total variance. However, the individual level variance is fixed to $\pi^{2} / 3$ in logistic regressions; therefore, this can only be used as a rough measure of the variance shares.

\section{Results}

Before turning to the multilevel analysis, a brief descriptive analysis of country differences in the purchases of environmental-labelled goods is presented. Figure 2 shows the country means of the respondents that reported to have bought an environmental friendly labelled product in the last month before the Eurobarometer survey was conducted and the per capita expenditure for organic food in Euros.

Both kinds of data reflect a similar ordering of countries. Yet, the per capita expenditures for organic food in some countries, like Sweden and Germany, deviate from the pattern that can be seen in the Eurobarometer data. Nevertheless, two problems arise when comparing the data: On the one hand, the Eurobarometer data do not capture the frequency of purchases and on the other hand, organic goods are only one type of product that carries an environmental label. To get a more precise comparison, data on the sales of eco-labelled goods would have to be added, but such information is not available. In the following descriptive analysis, the focus will be on the differences in the Eurobarometer survey data only.

There is a large variation in the purchase of environmental-labelled goods across the 18 European countries. While in Portugal only $7 \%$ of the respondents reported to have bought a labelled product, in Sweden $43 \%$ of the interviewees report such behaviour. With some distance, the group of Sweden, Denmark, Austria, and Luxembourg stands out as the leading countries in this kind of sustainable consumption, even though the two Scandinavian countries score higher than Austria and Luxembourg. This group is followed by Finland and Great Britain, which have a 7\% to $8 \%$ lower share of environmental label shoppers. A large group of Western European and surprisingly, the Czech Republic as the one Eastern European country have around $17 \%$ of citizens that report to have bought environmental-marked products. Finally, the rest of the Eastern European countries and especially the four southern European countries exhibit a low level of buying environmental-marked goods. Across all countries, on average $21 \%$ of the consumers participate in establishing sustainability through buying environmental-marked goods on the markets. Descriptively, there is mixed evidence that strong state involvement or low label fragmentation can makes a difference in sustainable buying. Of the leading four countries, two have medium (Sweden) or low (Luxembourg) state involvement and two have high state involvement (Denmark, Austria). However, the Czech Republic, which is characterized by strong state involvement in environmental labelling, is the leading Eastern European country, compared to Hungary and Poland characterized by a lower level of state involvement. A similar result can be observed for the fragmentation or plurality of labels. To further test the hypotheses, especially for the remaining continuous supply-side market variables, a multilevel analysis was conducted.

The multivariate multilevel regression analysis allows one to assess whether organizational and supply-side variables have a significant effect on the purchase of environmentallabelled goods and whether this effect persists when controlling for other (demand-side) variables. To assess whether there is sufficient variation on the macro level, the ICC is estimated for an empty model (without any variables). The ICC is $10 \%$ which is sufficiently 
high for estimating a multilevel model (Hox 2002). Thus $10 \%$ of the overall variance is linked to the macro level. Table 2 presents the results for the first set of logistic hierarchical regressions. Models 1 and 2 report the coefficients for the micro variables and the organizational and market supply-side factors. In Model 3, both types of variables are jointly introduced to the model.

As can be seen in Models 1 to 3, most of the effects of the individual level variables have a statistically significant effect (at least $p<.10$ ) and point in the predicted direction. Being mainly interested in the structural effects, the results of the individual level variables are only briefly discussed. The age squared term in the model controls for the curvilinear effect of age. With increasing age, the chance of buying sustainable goods first increases, but at a certain threshold, as the negative effect for age squared indicates, decreases again. As found by most other studies on sustainable consumption, women are more likely to consider the environment when shopping. Respondents with secondary or tertiary education are more likely to buy environmental-labelled products than respondents with primary education. As predicted, individuals holding pro-environmental values have a greater

Table 2 Logistic hierarchical regression models of purchasing environmental-labelled goods, unstandardized regression coefficients

\begin{tabular}{lccccccc}
\hline Variable & Model 1 & & Model 2 & & Model 3 & \\
\hline Constant & $-5.40^{* * *}$ & $(0.31)$ & $-5.01^{* * *}$ & $(0.24)$ & $-4.95^{* * *}$ & $(0.30)$ \\
Individual effects & & & & & & \\
Age & $0.05^{* * *}$ & $(0.01)$ & $0.05^{* * *}$ & $(0.01)$ & $0.05^{* * *}$ & $(0.01)$ \\
Age ${ }^{2}$ & $-0.00^{* * *}$ & $(0.00)$ & $-0.00^{* * *}$ & $(0.00)$ & $-0.00^{* * *}$ & $(0.00)$ \\
Female (Ref.: male) & $0.35^{* * *}$ & $(0.04)$ & $0.35^{* * *}$ & $(0.04)$ & $0.35^{* * *}$ & $(0.04)$ \\
Education level (Ref.: primary education) & & & & & & \\
Secondary education & $0.13^{*}$ & $(0.06)$ & $0.13^{*}$ & $(0.06)$ & $0.13^{*}$ & $(0.06)$ \\
Tertiary education & $0.38^{* * *}$ & $(0.07)$ & $0.39^{* * *}$ & $(0.07)$ & $0.39^{* * *}$ & $(0.07)$ \\
Pro-environmental values & $0.48^{* * *}$ & $(0.04)$ & $0.48^{* * *}$ & $(0.04)$ & $0.48^{* * *}$ & $(0.04)$ \\
Class scheme (Ref.: lower technical and routine & occupation) & & & & & \\
Service class & $0.46^{* * *}$ & $(0.06)$ & $0.45^{* * *}$ & $(0.06)$ & $0.45^{* * *}$ & $(0.06)$ \\
Intermediate employee & $0.29^{* * *}$ & $(0.06)$ & $0.28^{* * *}$ & $(0.06)$ & $0.28^{* * *}$ & $(0.06)$ \\
Small employers and self-employed & $0.20^{*}$ & $(0.09)$ & $0.20^{*}$ & $(0.09)$ & $0.20^{*}$ & $(0.09)$ \\
Lower services, sales and clerical occupation & $0.29^{* * *}$ & $(0.07)$ & $0.28^{* * *}$ & $(0.07)$ & $0.28^{* * *}$ & $(0.07)$ \\
Contextual effects & & & & & & \\
State involvement (Ref.: weak state involvement) & & & & & & \\
Medium state involvement & 0.06 & $(0.32)$ & & & -0.25 & $(0.25)$ \\
Strong state involvement & 0.33 & $(0.26)$ & & & -0.16 & $(0.24)$ \\
Plurality of labels & $-0.48^{*}$ & $(0.24)$ & & & -0.12 & $(0.21)$ \\
Density of small retailers & & & $-0.03^{* * *}$ & $(0.01)$ & $-0.03^{* *}$ & $(0.01)$ \\
Market supply & & & $0.25^{*}$ & $(0.11)$ & $0.29 *$ & $(0.12)$ \\
Variance and fit-statistics & & & & & & & \\
Variance random intercept & $0.23^{* * *}$ & $(0.08)$ & $0.13^{* * *}$ & $(0.05)$ & $0.12^{* * *}$ & $(0.04)$ \\
$\Delta$ Deviance (-2*LL) & 4.6 & & $13.9^{* *}$ & & $15.3^{* *}$ & \\
Residual ICC & 0.065 & & 0.039 & & 0.036 & \\
\hline
\end{tabular}

Eurobarometer 68.2, 2007; own calculations. Standard errors are in the parentheses

${ }^{*} p<.05,{ }^{* *} p<.01,{ }^{* * *} p<.001$ - significance levels 
propensity for reporting consumption of labelled goods. The five class positions are ranked hierarchically in the table, with the service class being the highest class. The lower technical and routine occupations as the lowest class make up the reference category. Interviewees in all other classes are more likely to report having bought environmental-labelled goods than respondents from the lower technical and routine occupations. Assuming that class position also indicates economic status, people materially better off and thus facing less budget restrictions are more likely to buy in an environmentally responsible manner.

Introducing the variables measuring state involvement and fragmentation of labelling arrangements, only the later variable has a significant, negative, effect (Model 1). Thus when a high plurality of labels exists in a country, the likelihood of buying environmentally labelled goods is low (H2). Looking at the $\Delta$ deviance, the organizational aspects of environmental labelling do not significantly contribute to explaining the variance in buying environmentally marked goods. A different picture emerges when controlling for the market supply-side variables. These factors significantly improve the model fit. As hypothesized, market supply of environmental-labelled goods (H3) has a significant positive effect and the higher the relative number of small retailers to customers in a country (H4) the less likely people are to consume sustainably. Yet, the supply of labelled products is not fully exogenous to purchases of environmental-labelled goods because the supply is likely to increase with consumer demand. Thus, preceding purchases of environmental-labelled goods might have triggered the level of supply of labelled goods measured here. Therefore the effect of this variable should be interpreted with some care. In Model 3, both organizational as well as supply-side factors are included together. As a consequence, the plurality of the labels indicator loses its significance and the model fit increases only modestly compared to Model 2 (from $\Delta$ deviance 13.9 to $\Delta$ deviance 15.3).

In Models 4 to 9, the effect of the demand-side political factors and the supply-side market factors are tested against the three most central control variables: The average per capita income of a country, share of post-materialist value orientations, and the level of generalized trust. Since post-materialist value orientation was the only variable that significantly explained organic food consumption in Sønderskov's (2009) study, the share of post-materialists in a country was introduced on the macro level, while at the same time excluding the pro-environmental value concept on the micro level to prevent multicollinearity. The individual level variables have been included, but results are not shown as their effect proved to be quite stable over all models (Tables 3 and 4).

In Model 4, per capita income is added to the organizational variables. Interestingly, when controlling for GDP per capita, state involvement has a positive significant effect in both variables. Thus level of income might be an underlying condition for rendering state involvement meaningful. Introducing the second demand-side variable, share of postmaterialists again renders strong state involvement, but also labels plurality significant (Model 5). Nevertheless, when controlling for generalized trust, all organizational effects vanish. Thus if people consider their fellow citizens as generally trustworthy, they are more willing to contribute to sustainability by purchasing environmental-labelled goods.

For the organizational dimension, it is difficult to draw a simple conclusion. Only when controlling for the demand for labelled products (as per capita income and share of citizens with post-materialist value orientations) does state involvement into labelling seem to matter. Plurality of labels has a significant effect on post-materialist values both with and without controls. However, when controlling for supply-side characteristics and generalized trust, both these organizational aspects do not significantly affect individual purchases of environmental-labelled goods. To test the conditionality of the organizational effects on demand-side factors, as well as trust and supply-side characteristics, some more models 
Table 3 Logistic hierarchical regression models (Models 4 to 6) of purchasing environmental-labelled goods, unstandardized regression coefficients

\begin{tabular}{|c|c|c|c|c|c|c|}
\hline \multirow{2}{*}{$\frac{\text { Variable }}{\text { Constant }}$} & \multicolumn{2}{|l|}{ Model 4} & \multicolumn{2}{|l|}{ Model 5} & \multicolumn{2}{|l|}{ Model 6} \\
\hline & $-5.40 * * *$ & $(0.28)$ & $-5.53 * * *$ & $(0.28)$ & $-5.03 * * *$ & $(0.29)$ \\
\hline \multicolumn{7}{|l|}{ Contextual Effects } \\
\hline \multicolumn{7}{|c|}{ State involvement (Ref.: weak state involvement) } \\
\hline Medium state involvement & $0.47^{+}$ & $(0.27)$ & 0.24 & $(0.24)$ & 0.03 & $(0.23)$ \\
\hline Strong state involvement & $0.45^{*}$ & $(0.20)$ & $0.42^{*}$ & $(0.20)$ & 0.01 & $(0.21)$ \\
\hline Plurality of labels & 0.19 & $(0.20)$ & $-0.60 * *$ & $(0.19)$ & -0.00 & $(0.21)$ \\
\hline Per Capita Income & $0.04 * * *$ & $(0.01)$ & & & & \\
\hline Post-Materialist Values (macro) & & & $4.79^{* * *}$ & $(1.37)$ & & \\
\hline Trust & & & & & $0.51 * * *$ & $(0.13)$ \\
\hline \multicolumn{7}{|l|}{ Variance and fit-statistics } \\
\hline Variance Random Intercept & $0.13^{* * *}$ & $(0.03)$ & $0.13 * * *$ & $(0.07)$ & $0.12 * * *$ & $(0.03)$ \\
\hline$\Delta$ Deviance $(-2 *$ LL $)$ & $14.24 * *$ & & $13.90 * * *$ & & $15.74 * *$ & \\
\hline Residual ICC & 0.039 & & 0.039 & & 0.035 & \\
\hline
\end{tabular}

Eurobarometer 68.2, 2007; own calculations. Standard errors are in the parentheses ${ }^{+} p<.1,{ }^{*} p<.05, * * p<.01, * * * p<.001$ - significance levels

were estimated with six variables (not reported). But again, when controlling for both per capita income and trust, the effect of state involvement and the plurality of labels vanishes. In sum, neither the involvement of the state nor the fragmentation of the eco-labels has a robust effect on the purchases of environmental-labelled goods.

Turning to market supply-side explanations, a different pattern emerges. Both the structure of the retailing market and the supply of (environmental) labelled goods have a robust significant influence on self-reported purchases of environmental friendly goods, when introducing the control variables (Models 7 to 9). Considering the financial

Table 4 Logistic hierarchical regression models (Models 7 to 9) of purchasing environmental-labelled goods, unstandardized regression coefficients

\begin{tabular}{|c|c|c|c|c|c|c|}
\hline Variable & Model 7 & & Model 8 & & Model 9 & \\
\hline Constant & $-5.02 * *$ & $(0.23)$ & $-5.01 * *$ & $(0.23)$ & $-5.02 * *$ & $(0.23)$ \\
\hline \multicolumn{7}{|l|}{ Contextual Effects } \\
\hline Density of small retailers & $-0.02 *$ & $(0.01)$ & $-0.04 * *$ & $(0.01)$ & $-0.02^{+}$ & $(0.01)$ \\
\hline Market supply & $0.28 * *$ & $(0.08)$ & $0.17^{+}$ & $(0.10)$ & $0.16^{+}$ & $(0.10)$ \\
\hline Per Capita Income & $0.04 * *$ & $(0.01)$ & & & & \\
\hline Post-Materialist Values (macro) & & & $3.08^{*}$ & $(1.15)$ & & \\
\hline Trust & & & & & $0.33 *$ & $(0.11)$ \\
\hline \multicolumn{7}{|l|}{ Variance and fit-statistics } \\
\hline Variance Random Intercept & $0.07 * *$ & $(0.05)$ & $0.09 * *$ & $(0.03)$ & $0.09 * *$ & $(0.04)$ \\
\hline$\Delta$ Deviance $(-2 * \mathrm{LL})$ & $24.16^{* *}$ & & $19.95^{* *}$ & & $20.79 * *$ & \\
\hline Residual ICC & 0.022 & & 0.028 & & 0.026 & \\
\hline
\end{tabular}

Eurobarometer 68.2, 2007; own calculations. Standard errors are in the parentheses

${ }^{+} p<.1, * p<.01,{ }^{* *} p<.001$ - significance levels 
opportunity structure on the demand-side and product provision as well as the retailing structures on the supply-side (Model 7) all prove to greatly increase the model fit when compared to all other models ( $\Delta$ deviance 24.16). By controlling for post-materialist value orientations (Model 8) and generalized trust (Model 9), the market supply variables retain a significant effect on purchases of eco-marked products. In sum, market supply and demand as well as generalized trust seem the most important drivers of the consumption of environmental-labelled goods. ${ }^{6}$

\section{Conclusion and Discussion}

Environmental labelling is a highly political act, as it attempts to govern consumer behaviour towards arriving at a heightened level of sustainable development. In organizing environmental labelling, a large variety of different approaches and mixes of instruments exists. Here, the focus was on only two, albeit important dimensions of environmental labelling, the involvement of the State and the plurality of environmental labels. Furthermore, the often overlooked supply-side market structures have been evaluated for their impact on consumption of environmental-labelled products.

Testing the organizational factors against supply- and demand-side explanations, it has been found that state involvement in labelling and the confusion infused by a large number of labels do not have a robust effect on the consumption of environmental-labelled goods across Europe. However, when controlling for demand-side factors there is a significant influence of both organizational aspects in the expected direction. Only after controlling for generalized trust and supply-side characteristics does this effect vanish. The supply-side market structures, such as the supply of labelled products and the dominating types of retailing channels, have a robust significant effect in the expected direction. Accordingly, what really drives consumption of environmental-marked products seems to be the interplay of supply and demand characteristics in the marketplace. Furthermore, generalized trust serves as a powerful force that renders organizational differences subordinate. Denmark and Sweden, the countries with the highest numbers of consumers of environmental labels, have very different ways of organizing organic food labelling. Being high-trust countries, citizens seem to be ready to trust both private and public solutions in the provision of labelling.

In this study, it has been empirically shown that state involvement in environmental labelling does not play an important role for explaining cross-national differences in environmental-labelled consumption. However, it would be imprudent to neglect the key impetus that has been provided by states in establishing the market for environmentallabelled goods and in providing resources for the development of, for instance, new standards and criteria for environmental labels (Hofer 2000; Jordan et al. 2004; Kern et al. 2001). Even though the real dynamic in buying behaviour seems to stem from supply- and demand-side interaction, the state is crucial in controlling the certification and punishing label fraud. Without the rule of law provided by the state, such new environmental policy instruments would not be possible. Furthermore, the state has an important role in

\footnotetext{
${ }^{6}$ A higher number of models have been estimated, including some of the other discussed control variables, like natural pollution and the strength of environmental movement organizations. For space considerations and considering the importance of the controls used, these results are not presented. However, the effect of supply-side market factors prove to be robust and the organizational dimensions yield mixed empirical support.
} 
promoting the production of environmental-labelled goods through subsidies. This has not been part of the analysis due to data restrictions. However, for the 15 Western European countries in the sample, there are some data on state subsidies for organic agriculture (Dimitri and Oberholzer 2005). A correlation analysis of the public expenditure for support of organic land in 2001 and the actual share of organic agricultural land per country in 2003 reveals a moderate impact (Pearson $r=.54, p<.05$ ) of state subsidies on the cultivation of organic agriculture and therefore on the provision of organic goods. In the multilevel analysis, the supply of labelled goods has a robust effect on the reported purchases of environmental-labelled goods. Thus, the promotion of the supply of eco- or organiclabelled goods through the state seems more important for increasing consumption of environmental-marked products, than states' labelling and certification initiatives.

Interestingly, there was no support for the hypothesis that a plurality of labels undermines the consumption of labelled goods. This might be due to the fact that a multitude of labels is also a sign of a differentiated market with different consumer groups showing different conviction to public and private standards. Furthermore, some labels like the German Bio label are higher order labels that can be combined with farmers' association or corporate labels and hence help reduce the confusion surrounding a multitude of labels. Another possibility is that the proxy used for the multitude of labels might have been too imprecise to capture the amount of labels consumers are confronted with. Nevertheless, comparing the indicator used with estimates on the share of organic products that are marked with the most common organic label provided by Hamm and Gronefeld (2004), there is a large overlap. For instance, in France, which has been coded as having a plurality of labels, only $66 \%$ of the products are estimated to have the "AB-Logo" in 2004, whereas in The Netherlands (here coded as not fragmented) 93\% of all organic products are estimated to carry the "EKO" label (Hamm and Gronefeld 2004). Needing more research for this dimension, a first conclusion suggested by the comparative analysis is that a large amount of labels does not necessarily discourage consumers from buying labelled goods. However, if taken as an indicator for a differentiated market, it also does not foster the purchase of environmental-labelled goods.

Another important empirical finding is the impact of the retailing structure. The increased concentration of retailers in some countries is accompanied by higher shares of labelled consumption. This is a double movement like development (Polanyi 1963), where the dis-embedding of consumers from producers is accompanied by a reembedding through buying environmental-labelled products. Retailers are by no means passive; they play an active and important role in providing opportunities and develop new markets where state or private actors have not (yet) managed to establish common labels.

As noted in the "Introduction" section, buying environmental-marked goods is only one dimension of sustainable consumption. The low number of people that reported purchases of labelled goods in the Southern European countries does not necessarily mean that people there consume less sustainably. By purchasing local products, or shopping close by at market stalls, people in these countries might rely on other ways of consuming sustainably. Thus, buying labelled goods might well be a functional equivalent to other forms of sustainable consumption spurred and institutionalized by differing market and retailing conditions. In the future, more research is needed to take into account different patterns of sustainable consumption, the organizational varieties of environmental labelling arrangements, as well as differing market structures. This would help to further understand the complex dynamics and path-dependent developments that have shaped the markets for sustainable goods. 
Acknowledgments I would like to thank two anonymous reviewers as well as the two editors for their valuable comments. Moreover, I would like to thank my colleagues for constructive discussions and especially Julian Brückner for important remarks.

\section{References}

Aschemann, J., Hamm, U., Naspetti, S., et al. (2007) The Organic Market. In: Lockeretz W (ed) Organic Farming. An International History (pp. 123-151). Wallingford: CABI.

Baumol, W. J., Oates, W. E., \& Blackman, S. A. (1979). Economics, environmental policy and the quality of life. Englewood Cliffs: Prentice Hall.

Ben Youssef, A., \& Abderrazak, C. (2009). Multiplicity of eco-labels, competition, and the environment. Journal of Agricultural and Food Industrial Organization, 7, Article 7.

Bjørner, T. B., Hansen, L. G., \& Russell, C. S. (2004). Environmental labeling and consumers' choice-An empirical analysis of the effect of the Nordic Swan. Journal of Environmental Economics and Management, 47, 411-434.

Boström, M. (2006). Regulatory credibility and authority through inclusiveness: Standardization organizations in cases of eco-labelling. Organization, 13, 345-367.

Boström, M., \& Klintman, M. (2006). State-centered versus nonstate-driven organic food standardization: A comparison of the US and Sweden. Agriculture and Human Values, 23, 163-180.

Boström, M., \& Klintman, M. (2008). Eco standards, product labelling and green consumerism. Houndmills: Palgrave Macmillan.

Bourdieu, P., (1984). La distinction: Critique sociale du jugement. Paris: Les Ed. de Minuit.

Chiles, T. H., \& McMackin, J. F. (1996). Variable risk preferences, trust, and transaction cost economics. Academy of Management Review, 21, 73-99.

Clarke, R., Davies, S., Dobson, P., \& Waterson, M. (2002). Buyer power and competition in European food retailing. Cheltenham: Edward Elgar Publishing.

Crespi, J. M., \& Marette, S. (2005). Eco-labelling economics: Is public involvement necessary? In S. Krarup \& C. S. Russell (Eds.), Environment, information and consumer behaviour (pp. 93-109). Cheltenham: Edward Elgar.

Dabbert, S., Harring, A. M., \& Zanoli, R. (2004). Organic farming: Policies and prospects. London: Zed Books.

Diekmann, A., \& Preisendörfer, P. (2003). Green and greenback: The behavioral effects of environmental attitudes in low-cost and high-cost situations. Rationality and Society, 15, 441-472.

Dimitri, C., \& Oberholzer, L. (2005). Market-led versus government-facilitated growth: Development of the U.S. and EU organic agricultural sectors. Washington, DC: United States Department of Agriculture.

Dunlap, R. E., George H. Gallup, J., \& Gallup, A. M. (1993). Of global concern: Results of the health of the planet survey. Environment, 35, 7-15, 33-39.

Dytrtová, K. (2008). Organic Farming in the Czech Republic 2006. Retrieved Nov 19, 2009, from http:// www.organic-europe.net/country_reports/czech_republic/default.asp.

Erikson, R., \& Goldthorpe, J. H. (1992). The constant flux: A study of class mobility in industrial societies. Oxford: Clarendon.

ESS (2004). European Social Survey Round 2 Data (Vol. Data file edition 3.1). Norway: Norwegian social science data services-Data archive and distributor of ESS data.

ESS (2006). European Social Survey Round 3 Data (Vol. Data file edition 3.2). Norway: Norwegian social science data services - Data archive and distributor of ESS data.

European Commission (2007). List of bodies or authorities in charge of inspection provided for in article 15 of regulation (EEC) No 2092/91. Retrieved June 25, 2010, from http://eur-lex.europa.eu/JOHtml.do? uri=OJ:C:2008:013:SOM:EN:HTML.

European Commission (2008). Attitudes of European citizens towards the environment. Special Eurobarometer Report. Retrieved December 12, 2009, from http://ec.europa.eu/public_opinion/archives/ebs/ ebs_295_en.pdf.

European Commission (2010). Other Ecolabels. Retrieved May 16, 2010, from http://ec.europa.eu/ environment/ecolabel/useful_links/other_ecolabels_en.htm.

Eurostat (2009a). Structural business statistics: Eurostat.

Eurostat (2009b). Eco-label awards by products. Retrieved Dec. 10, 2009, from http://epp.eurostat.ec.europa. eu/portal/page/portal/eurostat/home/.

EVS (2006). European and world values surveys four-wave integrated data file, 1981-2004, version: 20060423. Retrieved download: 30.4.2006, from http://www.jdsurvey.net/web/evs1.htm. 
Ferrer, M., \& Fraile, M. (2006). Exploring the social determinants of political consumerism in Western Europe. UAM Estudio/Working Paper 57.

Fuchs, D. A., \& Lorek, S. (2005). Sustainable consumption governance: A history of promises and failures. Journal of Consumer Policy, 28, 261-288.

Global Ecolabelling Network (2003). Global Ecolabelling Network News, 15. Retrieved Jan. 24, 2010, from http://www.globalecolabelling.net/pdf/gen15.pdf.

Global Ecolabelling Network (2006). Annual Report 2006. Retrieved Jan. 24, 2010, from http://www. globalecolabelling.net/pdf/06annual report06.pdf.

Global Ecolabelling Network (2007). Global Ecolabelling Network News, 21. Retrieved Jan. 24, 2010, from http://www.globalecolabelling.net/pdf/gen21.pdf.

Goul Andersen, J., \& Tobiasen, M. (2004). Who are these political consumers anyway? Survey evidence from Denmark. In M. Micheletti, A. Follesdal, \& D. Stolle (Eds.), Politics, products, and markets (pp. 203-221). London: Transaction Publishers.

Grunert, K. G., Baadsgard, A., Hartvig Larsen, H., \& Koed Madsen, T. (1996). Market orientation in food and agriculture. Dordrecht: Kluwer Academic Publishers.

Guido, G., Prete, M. I., \& Pino, G. (2009). The impact of ethical self-identity and safety concerns on attitudes and purchasing intentions of organic food products. In G. Guido (Ed.), Behind ethical consumption: Purchasing motives and marketing strategies for organic food products, non-GMOs, bio-fuels (pp. 7393). Bern: Peter Lang.

Hamm, U., \& Gronefeld, F. (2004). The European market for organic food: Revised and updated analysis (Vol. 5). Aberystwyth: School of management and business.

Harrington, L., \& Damnics, M. (2004). Energy labelling and standards programs throughout the world. NAEEEC Report 2004/04. The national appliance and equipment energy efficiency committee, Australia. Retrieved Dec. 10, 2009, from http://www.energyrating.gov.au/library/pubs/200404-internatlabelreview.pdf.

Hofer, K. (2000). Labelling of organic food products. In A. Mol, V. Lauber, \& D. Liefferink (Eds.), The voluntary approach to environmental policy. Joint environmental policy-making in Europe (pp. 156191). Oxford: Oxford University.

Holzer, B. (2006). Political consumerism between individual choice and collective action: Social movements, role mobilization and signaling. International Journal of Consumer Studies, 30, 406-415.

Hox, J. (2002). Multilevel analysis. Techniques and applications. New Jersey: Lawrence Erlbaum Associates.

Inglehart, R. (1995). Public support for the environmental protection: Objective problems and subjective values in 43 societies. Political Science and Politics, 28, 57-72.

Inglehart, R. (1997). Modernization and postmodernization: Cultural, economic, and political change in 43 societies. Princeton: Princeton University.

Jordan, A., Wurzel, R. K. W., Zito, A. R., \& Brückner, L. (2004). Consumer responsibility-Taking and eco-labeling schemes in Europe. In M. Micheletti, A. Follesdal, \& D. Stolle (Eds.), Politics, products, and markets: Exploring political consumerism past and present (pp. 161-180). New Brunswick: Transaction Publishers.

Kern, K., Kissling-Näf, I., Landmann, U., Mauch, C., \& Löffelsend, T. (2001). Policy convergence and policy diffusion by governmental and non-governmental institutions-An international comparison of eco-labeling systems. WZB Discussion Paper FS II 01-305, 66 p.

Kovács, A. (2008). Organic farming in Hungary 2005. Retrieved Nov. 19, 2009, from http://www.organiceurope.net/country reports/hungary/default.asp.

Krarup, S., \& Russell, C. S. (2005). Environment, information and consumer behaviour. Cheltenham: Edward Elgar.

Merton, R. K. (1996). On social structure and science. Chicago: University of Chicago.

Metera, D. (2008). Organic farming in Poland: Update July 2005, Retrieved Nov. 19, 2009, from http:// www.organic-europe.net/country_reports/poland/default.asp.

Micheletti, M. (2004). Why more women? Issues of gender and political consumption. In M. Micheletti, A. Follesdal, \& D. Stolle (Eds.), Politics, products, and markets (pp. 245-264). New Brunswick: Transaction Publishers.

Micheletti, M., \& Stolle, D. (2005). Swedish political consumers: Who they are and why they use the market as an arena for politics. In M. Boström, A. Føllesdal, M. Klintman, M. Micheletti, \& M. P. Sørensen (Eds.), Political Consumerism: Its motivations, power, and conditions in the Nordic countries and elsewhere (pp. 145-164). Copenhagen: Nordic Council of Ministers.

Micheletti, M., Follesdal, A., \& Stolle, D. (Eds.). (2004). Politics, products, and markets: Exploring political consumerism past and present. New Brunswick: Transaction Publishers.

Michelsen, J., Hamm, U., Wynen, E., \& Roth, E. (1999). The European market for organic products: Growth and development (Vol. 7). Hohenheim: Universität Hohenheim.

Mol, A., Lauber, V., \& Liefferink, D. (Eds.). (2000). The voluntary approach to environmental policy: Joint environmental policy-making in Europe. Oxford: Oxford University. 
Murphy, J. (2001). From production to consumption: Environmental policy in the European Union. In M. J. Cohen \& J. Murphy (Eds.), Exploring sustainable consumption: Environmental policy and the social sciences (pp. 39-58). Oxford: Elsevier Sciences.

Nelson, P. (1978). Information and consumer behavior. The Journal of Political Economy, 2, 311-329.

OECD (1997). Eco-labelling: Actual effects of selected programmes. Paris: Organization for Economic Cooperation and Development.

OECD (2002). Towards sustainable household consumption? Trends and policies in OECD countries. Paris: Organization for Economic Co-operation and Development.

OECD (2005). Effects of eco-labelling schemes: Compilation of recent studies. Paris: Organization for Economic Co-operation and Development.

Ostrom, E. (1990). Governing the commons. Cambridge: Cambridge University.

Padel, S., \& Midmore, P. (2005). The development of the European market for organic products: Insights from a Delphi study. British Food Journal, 107, 626-647.

Padel, S., Schaack, D., \& Willer, H. (2009). Development of the organic market in Europe. In H. Willer \& L. Kilcher (Eds.), The world of organic agriculture: Statistics and emerging trends 2009 (pp. 155-163). Geneva: IFOAM.

Pfeiffer, M. (2009). Public opinion on state responsibility for minimum income protection: A comparison of 14 European countries. Acta Sociologica, 52, 117-134.

Pinton, R., Zanoli, R., \& Helga, W. (2008). Organic farming in Italy 2007. Retrieved Nov. 19, 2009, from $\mathrm{http} / / /$ www.organic-europe.net/country_reports/italy/default.asp.

Polanyi, K. (1963). The great transformation: The political and economic origins of our time. Beacon Hill: Beacon.

Rabe-Hesketh, S., \& Skorndal, A. (2008). Multilevel and longitudinal modeling using Stata (2nd ed.). College Station: Stata.

Research Institute for Organic Agriculture (2009). Country reports. Retrieved Sep. 28, 2009, from http:// www.organic-europe.net/country_reports/default.asp.

Richter, T. (2005). The organic market in Germany. Overview and information on market access. Bonn: Geschäftsstelle Bundesprogramm Ökologischer Landbau in der Bundesanstalt für Landwirtschaft und Ernährung (BLE).

Roosen, J., Lusk, J. L., \& Fox, J. A. (2003). Consumer demand for and attitudes toward alternative beef labeling strategies in France, Germany, and the UK. Agribusiness, 19, 77-90.

Rundgren, G. (2002). Overview of the implementation of the EU organic regulatory system. The Organic Standard, 9, 3-10.

Russell, C. S., Krarup, S., \& Clark, C. D. (2005). Environment, information and consumer behaviour: An introduction. In S. Krarup \& C. S. Russell (Eds.), Environment, information and consumer behaviour (pp. 1-29). Cheltenham: Edward Elgar.

Schaer, B. (2009). The organic market in Europe: Trends and challenges. In H. Willer \& L. Kilcher (Eds.), The world of organic agriculture. Statistics and emerging trends 2009 (pp. 164-167). Geneva: IFOAM.

Schmid, O. (2007). Development of standards for organic farming. In W. Lockeretz (Ed.), Organic farming: An international history (pp. 152-186). Wallingford: CABI.

Snijders, T. A. B., \& Bosker, R. J. (1999). Multilevel analysis. London: Sage.

Sønderskov, K. M. (2009). Different goods, different effects: Exploring the effects of generalized social trust in large-N collective action. Public Choice, 14, 145-160.

Sønderskov, K. M., \& Daugbjerg, C. (2010). Eco-labelling, the state and consumer confidence. Paper presented at the 60th Political Studies Association Annual Conference, Edinburgh, UK.

Southerton, D., Chappells, H., \& Van Vliet, B. (Eds.). (2004). Sustainable consumption: The implications of changing infrastructures of provision. Cheltenham: Edward Elgar.

Spaargaren, G. (2004). Sustainable consumption: A theoretical and environmental policy perspective. In D. Southerton, H. Chappells, \& B. van Vliet (Eds.), Sustainable consumption: The implications of changing infrastructures of provision (pp. 15-31). Cheltenham: Edward Elgar.

Sparks, P., \& Shepherd, R. (1992). Self-identity and the theory of planned behavior: Assessing the role of identification with "green consumerism". Social Psychology Quarterly, 55, 388-399.

Stolle, D., Hooghe, M., \& Micheletti, M. (2005). Politics in the supermarket: Political consumerism as a form of political participation. International Political Science Review, 26, 245-269.

Strømsnes, K. (2005). Political consumption in Norway: Who, why-and does it have any effect? In M. Boström, A. Føllesdal, M. Klintman, M. Micheletti, \& M. P. Sørensen (Eds.), Political consumerism: Its motivations, power, and conditions in the Nordic countries and elsewhere (pp. 165-181). Copenhagen: Nordic Council of Ministers.

Teisl, M. F., \& Roe, B. (2005). Evaluating the factors that impact the effectiveness of eco-labelling programmes. In S. Krarup \& C. S. Russell (Eds.), Environment, information and consumer behaviour (pp. 65-90). Cheltenham: Edward Elgar. 
Teisl, M. F., Rubin, J., \& Noblet, C. L. (2008). Non-dirty dancing? Interactions between eco-labels and consumers. Journal of Economic Psychology, 29, 140-159.

Terragni, L., \& Kjærnes, U. (2005). Ethical consumption in Norway: Why is it so low? In M. Boström, A. Føllesdal, M. Klintman, M. Micheletti, \& M. P. Sørensen (Eds.), Political consumerism: Its motivations, power, and conditions in the Nordic countries and elsewhere (pp. 471-485). Copenhagen: Nordic Council of Ministers.

Thøgersen, J. (2000). Psychological determinants of paying attention to eco-labels in purchase decisions: Model development and multinational validation. Journal of Consumer Policy, 23, 285-313.

Thøgersen, J. (2002). Promoting "green" consumer behaviour with eco-labels. In T. Dietz \& P. C. Stern (Eds.), New tools for environmental protection: Education, information, and voluntary measures (pp. 83-104). Washington, DC: National Academy.

Thøgersen, J. (2005). How may consumer policy empower consumers for sustainable lifestyles? Journal of Consumer Policy, 28, 143-178.

Thøgersen, J. (2010). Country differences in sustainable consumption: The case of organic food. Journal of Macromarketing, 30, 171-185.

van Amstel, M., Driessen, P., \& Glasbergen, P. (2008). Eco-labeling and information asymmetry: A comparison of five eco-labels in the Netherlands. Journal of Cleaner Production, 16, 263-276.

Van de Vjver, F. J. R., Van Hemert, D. A., \& Poortinga, Y. H. (Eds.). (2008). Multilevel analysis of individuals and cultures. New York: Lawrence Erlbaum Associates.

Veblen, T. (1949). A theory of the leisure class. London: Allen and Unwin.

Vorley, B. (2007). Supermarkets and agri-food supply chains in Europe: Partnership and protest. In D. Burch \& G. Lawrence (Eds.), Supermarkets and agri-food supply chains: Transformations in the production and consumption of foods. Cheltenham: Edward Elgar.

Wier, M., \& Carlverley, C. (2002). Market potential for organic foods in Europe. British Food Journal, 104, 45-62.

Willer, H., \& Kilcher, L. (Eds.). (2009). The world of organic agriculture. Statistics and emerging trends 2009. Bonn; Frick; Geneva: IFOAM; FiBL; ITC.

Willer, H., \& Yussefi, M. (Eds.). (2007). The world of organic agriculture: Statistics and emerging trends 2007. (Vol. 9). Bonn: International federation of organic agriculture movements.

Williamson, O. E. (1981). The economics of organization: The transaction cost approach. The American Journal of Sociology, 87, 548-577.

Worldbank (2009). World Bank World Development Indicators 2009. Retrieved Sep. 28, 2009, from http:// data.worldbank.org/data-catalog/world-development-indicators/wdi-2009.

Zanoli, R. (Ed.). (2004). The European consumer and organic food (Vol. 7). Aberystwyth: University of Wales. 